\title{
Efektivitas Pemeriksaan Serologis Sifilis
}

\section{Tirsa W. I. Baguna, ${ }^{1}$ Nurdjannah J. Niode, ${ }^{2}$ Herry E. J. Pandaleke ${ }^{2}$}

\author{
${ }^{1}$ Program Studi Pendidikan Dokter Fakultas Kedokteran Universitas Sam Ratulangi Manado \\ Sulawesi Utara, Indonesia \\ ${ }^{2}$ Bagian Ilmu Kesehatan Kulit dan Kelamin Fakultas Kedokteran Universitas Sam Ratulangi \\ Manado, Sulawesi Utara, Indonesia \\ Email: tirsa_aicha@yahoo.com
}

\begin{abstract}
High prevalence of syphilis can be reduced by doing screening. Tests used for screening and diagnosis of syphilis are serological tests of syphilis consisting of nontreponemal tests and treponemal tests. Nontreponemal tests consist of Rapid Plasma Reagin (RPR) and Venereal Disease Research Laboratory (VDRL) meanwhile Treponemal tests consist of Treponema Pallidum Haemagglutination Assay (TPHA) and Treponema Pallidum Rapid (TP Rapid). This study was aimed to determine the effectiveness of syphilis serological tests. This was a literature review study using the keywords namely serology OR serological OR serologic AND syphilis in PubMed and ClinicalKey. The literatures were written in English and/or Indonesian, published in the last 10 years (2011-2020), and can be accessed in full text. The results obtained 25 literatures. High sensitivity was found in RPR of 9.1\%-100\%, VDRL of $44.4 \%-100 \%$, and TP Rapid of 50.0\%-100\%. High specificity was found in TPHA of $99.7 \%$ and TP Rapid of $85.3 \%-100 \%$. In conclusion, effective syphilis screening is performed with RPR and VDRL, while effective syphilis diagnostic is performed with TP Rapid and TPHA.

Keywords: syphilis, serology tests, effectiveness of tests
\end{abstract}

\begin{abstract}
Abstrak: Prevalensi kasus sifilis yang tinggi dapat diturunkan dengan adanya skrining. Pemeriksaan yang digunakan untuk skrining dan diagnosis sifilis ialah pemeriksaan serologis sifilis, terdiri atas pemeriksaan serologis non spesifik treponema dan pemeriksaan serologis spesifik treponema. Pemeriksaan serologis non spesifik treponema antara lain Rapid Plasma Reagin (RPR) dan Venereal Disease Research Laboratory (VDRL). Pemeriksaan serologis spesifik treponema antara lain Treponema Pallidum Haemagglutination Assay (TPHA) dan Treponema Pallidum Rapid (TP Rapid). Penelitian ini bertujuan untuk mengetahui efektivitas pemeriksaan serologis sifilis. Jenis penelitian ialah literature review menggunakan kata kunci serology OR serological OR serologic AND syphilis di PubMed dan ClinicalKey. Literatur yang digunakan memiliki bahasa Inggris dan/atau bahasa Indonesia, terbitan 10 tahun terakhir (20112020), dan dapat diakses teks lengkap. Sensitivitas tinggi ditemukan pada RPR sebesar 9,1\%100\%, VDRL sebesar 44,4\%-100\%, dan TP Rapid sebesar 50,0\%-100\%. Spesifisitas tinggi ditemukan pada TPHA sebesar 99,7\% dan TP Rapid sebesar 85,3\%-100\%. Simpulan penelitian ini ialah skrining sifilis efektif dilakukan dengan RPR dan VDRL, sedangkan diagnostik sifilis efektif dilakukan dengan TP Rapid dan TPHA.
\end{abstract}

Kata kunci: sifilis, pmeriksaan serologis, efektivitas pemeriksaan

\section{PENDAHULUAN}

Estimasi insidens kasus sifilis di dunia pada 2016 ialah sebanyak 6,3 juta. Prevalensi sifilis baik pada laki-laki maupun perempuan diperkirakan sekitar $0,5 \%{ }^{1}$
Sementera itu, data World Health Organization (WHO) pada 2019 menunjukkan di antara ibu hamil yang datang untuk pemeriksaan antenatal care (ANC) terdapat $3,2 \%$ positif terhadap sifilis. Sifilis pada 
kehamilan merupakan penyebab kedua dari kelahiran mati di dunia. ${ }^{2}$ Secara global, diestimasikan 200.000 kelahiran mati dan kematian neonatal terjadi akibat sifilis kongenital sebanyak $661.000 .^{3}$

Data di tahun 2019, rata-rata $11,8 \%$ dari 25 negara pun melaporkan kejadian sifilis pada lelaki yang berhubungan seks dengan lelaki (LSL). ${ }^{2}$ Selain itu, pada wanita penjaja seks (WPS) dengan sampel 22.048 di tahun 2011 didapatkan prevalensi sebesar 8,6\%. ${ }^{4}$ LSL, WPS, dan transgender merupakan kelompok berisiko untuk sifilis dan human immunodeficiency virus (HIV). ${ }^{5}$

Melalui Global Health Sector Strategy on Sexually Transmitted Infections (STIs) 2016-2021, WHO menargetkan penurunan $90 \%$ insidens sifilis dan $\leq 50$ kasus dari sifilis kongenital setiap 100.000 kelahiran hidup di $80 \%$ negara. Strategi yang dilakukan berfokus pada skrining, penatalaksanaan pada ibu hamil, dan mengontrol sifilis pada LSL dan WPS. ${ }^{5}$ Pada 2002-2012 terjadi penurunan sifilis kongenital dari 109,3 menjadi 9,4 kasus per 100.000 kelahiran hidup karena adanya peningkatan skrining dari $89,8 \%$ menjadi $97,2 \%$ pada ibu hamil. ${ }^{6}$ Sementara itu, skrining yang dilakukan pada LSL di 20 kota di Amerika Serikat meningkat dari 2008-2014, tetapi insidens dari sifilis yang dilaporkan pun ikut meningkat. Diduga peningkatan insidens sifilis terjadi bukan karena peningkatan skrining sifilis itu sendiri, tetapi karena terjadi peningkatan skrining untuk sifilis pada LSL yang HIV positif. ${ }^{7}$

Skrining dan diagnosis sifilis di Indonesia dilakukan dengan pemeriksaan serologis non spesifik treponema dan dilanjutkan dengan pemeriksaan serologis spesifik treponema. Jika hasil pemeriksaan serologis non spesifik treponema reaktif, pemeriksaan dilanjutkan dengan pemeriksaan serologis spesifik treponema. Jika hasil pemeriksaan serologis spesifik treponema reaktif, pemeriksaan titer Rapid Plasma Reagin (RPR) dilakukan untuk menentukan infeksi sifilis berada di stadium aktif atau laten. ${ }^{8}$

Pemeriksaan serologis non spesifik treponema terdiri atas RPR dan Venereal Disease Research Laboratory (VDRL).
Pemeriksaan ini mendeteksi antibodi $\operatorname{IgG}$ dan IgM terhadap materi lipid yang dilepaskan sel inang yang rusak dan Treponema pallidum (T. Pallidum). Penggunaan pemeriksaan ini untuk deteksi infeksi dan reinfeksi sifilis yang aktif, serta mengamati respon dari pengobatan. Hasil pemeriksaan dapat disajikan secara kualitatif sebagai reaktif atau non reaktif ataupun kuantitatif sebagai hasil reaktif dengan titer mulai dari $1: 1,1: 2,1: 4$, dan seterusnya. ${ }^{8,9}$

Pemeriksaan serologis spesifik treponema, terdiri atas Treponema Pallidum Haemagglutination Assay (TPHA), Treponema Pallidum Particle Agglutination Assay (TP-PA), Treponema Pallidum Rapid (TP Rapid), dan Fluorescent Treponemal Antibody Absorption (FTA-ABS). Pemeriksaan ini mendeteksi antibodi terhadap T. pallidum. Hasil reaktif pada pemeriksaan serologis spesifik treponema menunjukkan pernah atau sementara mengalami infeksi treponema. ${ }^{8,9}$

Tingginya prevalensi dan mortalitas yang disebabkan oleh sifilis membuat suatu kajian mengenai efektivitas pemeriksaan serologis sifilis untuk skrining dan diagnosis sifilis perlu dilakukan.

\section{METODE PENELITIAN}

Jenis penelitian ini ialah literature review yang dilakukan untuk mendapatkan pemahaman mendalam tentang efektivitas pemeriksaan serologis sifilis berdasarkan bukti pengetahuan yang ada sekarang tentang apa yang sudah diketahui dan belum diketahui. ${ }^{10,11}$ Pemeriksaan serologis yang diteliti dalam penelitian ini ialah RPR, VDRL, TPHA, dan TP Rapid.

Penelitian ini dilakukan melalui pencarian literatur pada database PubMed dan ClinicalKey dengan menggunakan kata kunci serology OR serological OR serologic AND syphilis. Literatur yang digunakan terbitan 10 tahun terakhir (2011-2020) yang bisa diakses full text, berbahasa Inggris dan/atau Indonesia, sesuai topik, serta memenuhi kriteria inklusi dan eksklusi.

Kriteria inklusi dan eksklusi dalam mencari literatur memakai PICOS framework, yang terdiri atas population/problem, intervention, comparison, outcome, dan 
study design. Tidak ada population/ problem, comparison, dan outcome tertentu yang dipakai. Sementara itu, intervention yang dipakai ialah pemeriksaan serologis sifilis. Desain penelitian yang dipakai mencakup clinical trial, randomized controlled trial, cross sectional, case control, cohort study, case study, dan case series.

\section{HASIL PENELITIAN}

Hasil pencarian literatur melalui publikasi pada PubMed dan ClinicalKey menggunakan kata kunci (serology OR serological OR serologic AND syphilis) mendapatkan literatur sebanyak 9374 menggunakan PubMed dan 839 menggunakan ClinicalKey $(n=10213)$. Berdasarkan tahun publikasi, bahasa, dan ketersediaan teks penuh, literatur diskrining dan didapatkan hasil sebanyak 738 menggunakan PubMed dan 623 menggunakan ClinicalKey ( $\mathrm{n}=1361)$. Literatur kemudian dilakukan skrining berdasarkan judul sesuai dengan topik literature review sehingga didapatkan 113 literatur dari PubMed dan 45 literatur dari ClinicalKey $(n=158)$. Selanjutnya, literatur diskrining abstraknya berdasarkan kriteria inklusi dari PICOS framework dan didapatkan literatur sebanyak 22 dari PubMed dan 3 dari ClinicalKey $(n=25)$. Literatur yang didapatkan dari seleksi studi pada database sebanyak 25 literatur. Satu literatur oleh Montaño et $\mathrm{al}^{12}$ memiliki desain penelitian cross-sectional sekaligus clinical trial. Tidak didapatkan literatur dengan desain penelitian randomized controlled trial dan case series yang memenuhi kriteria untuk pengkajian dalam literature review ini.

Penilaian efektivitas pemeriksaan serologis didasarkan terutama pada hasil sensitivitas dan spesifisitas. Literatur yang tidak menyertakan hasil sensitivitas dan spesifisitas dinilai berdasarkan hasil penting lainnya terkait efektivitas pemeriksaan serologis. Dari 25 literatur terdapat 5 literatur yang tidak menyertakan hasil sensitivitas dan spesifisitas, 1 literatur yang hanya menyertakan hasil sensitivitas, serta 19 literatur yang menyertakan hasil sensitivitas dan spesifisitas.

Tabel 1 menjabarkan efektivitas pemeriksaan serologis non spesifik treponema, yang terdiri atas 15 literatur, dimana 10 literatur membahas RPR, 3 literatur membahas VDRL, dan 2 literatur membahas RPR dan VDRL. Tabel 2 memperlihatkan sensitivitas RPR berdasarkan stadium sifilisnya yang dinilai oleh 2 literatur. Tabel 3 menunjukkan perbandingan efektivitas antara RPR otomatis dan RPR kartu oleh 3 literatur. Tabel 4 menjabarkan efektivitas pemeriksaan serologis spesifik treponema, yang terdiri atas 11 literatur, dimana 2 literatur membahas TPHA dan 9 literatur membahas TP Rapid.

Tabel 1. Efektivitas pemeriksaan serologis non spesifik treponema masing-masing literature

\begin{tabular}{|c|c|c|c|c|c|}
\hline \multirow[t]{2}{*}{ No. } & \multirow[t]{2}{*}{ Peneliti utama } & \multirow{2}{*}{$\begin{array}{c}\text { Pemeriksaan } \\
\text { serologis }\end{array}$} & \multicolumn{3}{|c|}{ Hasil } \\
\hline & & & $\begin{array}{c}\text { Sensitivitas } \\
(\%)\end{array}$ & $\begin{array}{c}\text { Spesifisitas } \\
(\%)\end{array}$ & Lainnya \\
\hline 1. & Shukla $\mathrm{M}^{13}$ & RPR & $63,2-100$ & - & - \\
\hline 2. & Maves RC ${ }^{14}$ & RPR & - & - & Positif palsu $8,2 \%$ \\
\hline 3. & Bosshard $\mathrm{PP}^{15}$ & VDRL & $61,0-97,0$ & 100 & - \\
\hline 4. & Versiani $\mathrm{I}^{16}$ & RPR & 100 & 100 & ICC 0,99 VDRL terhadap \\
\hline & & VDRL & - & - & RPR \\
\hline 5. & Marra $\mathrm{CM}^{17}$ & VDRL & $48,9-67,5$ & $74,0-91,2$ & - \\
\hline 6. & Lee $\mathrm{JH}^{18}$ & RPR & $52,5-86,4$ & 94,3 & $\begin{array}{l}P_{o} 78,6 \% \\
\kappa 0,565\end{array}$ \\
\hline 7. & Sanfilippo $\mathrm{AM}^{19}$ & RPR & $76,0-100$ & $99,4-99,8$ & $\begin{array}{l}\text { NRP } 80,7 \%-90,5 \% \\
\text { NRN 99,4\%-100\% } \\
\text { PPA 95,2\%-96,0\% } \\
\text { NPA 96,0\%-98,8\% } \\
\kappa 0,763-0,920\end{array}$ \\
\hline 8. & Negash $\mathbf{M}^{20}$ & RPR & 100 & 80,8 & NRP $76,2 \%$ \\
\hline
\end{tabular}




\begin{tabular}{|c|c|c|c|c|c|}
\hline \multirow{4}{*}{9.} & \multirow{4}{*}{ Marangoni $\mathrm{A}^{21}$} & \multirow[b]{3}{*}{ RPR } & \multirow[b]{3}{*}{9,1} & \multirow[b]{3}{*}{100} & \multirow{3}{*}{$\begin{array}{l}\text { NRN } 100 \% \\
P_{o} 88,0 \% \\
\text { NRP } 100 \% \\
\text { NRN } 65.5 \%\end{array}$} \\
\hline & & & & & \\
\hline & & & & & \\
\hline & & VDRL & 44,4 & 100 & $\begin{array}{l}\text { NRP 100\% } \\
\text { NRN 79.2\% }\end{array}$ \\
\hline 10. & Shukla $\mathrm{MR}^{22}$ & RPR & 88,2 & 100 & $\begin{array}{l}\text { NRIN } 19,2 \% \\
-\end{array}$ \\
\hline \multirow{2}{*}{11.} & Prynn $\mathrm{J}^{23}$ & RPR & - & - & Serum darah positif $1: 4$ \\
\hline & & & & & CSS negatif \\
\hline \multirow[t]{2}{*}{12.} & Mehra B ${ }^{24}$ & VDRL & 100 & 86,21 & NRP $84,0 \%$ \\
\hline & & & & & NRN $100 \%$ \\
\hline \multirow{6}{*}{$\begin{array}{l}13 . \\
14 .\end{array}$} & Motlagh $\mathrm{MN}^{25}$ & RPR & - & - & Negatif palsu pada skrining \\
\hline & Liu $C^{26}$ & RPR & 73,13 & 96,19 & NRP $82,45 \%$ \\
\hline & & & & & NRN 93,6\% \\
\hline & & & & & $\mathrm{LR}^{+} 0,28$ \\
\hline & & & & & LR $^{-} 19,2$ \\
\hline & & & & & Akurasi $86,22 \%$ \\
\hline \multirow[t]{3}{*}{15.} & Tsuboi $\mathrm{M}^{27}$ & RPR & 98,7 & 96,7 & NRP 92,5\% \\
\hline & & & & & NRN 99,4\% \\
\hline & & & & & $\kappa 0,94$ \\
\hline
\end{tabular}

Tabel 2. Sensitivitas pemeriksaan serologis non spesifik treponema berdasarkan stadium sifilis

\begin{tabular}{|c|c|c|c|c|c|}
\hline No. & Peneliti utama & $\begin{array}{l}\text { Pemeriksaan } \\
\text { serologis }\end{array}$ & Stadium sifilis & $\begin{array}{l}\text { Jumlah } \\
\text { sampel }\end{array}$ & Sensitivitas (\%) \\
\hline \multirow[t]{6}{*}{1.} & Shukla $\mathrm{M}^{13}$ & RPR & Primer & 21 & 95,2 \\
\hline & & & Sekunder & 46 & 91,3 \\
\hline & & & Laten awal & 30 & 90,0 \\
\hline & & & Laten akhir & 38 & 63,2 \\
\hline & & & $\begin{array}{ll}\text { Laten } & \text { tidak } \\
\text { terklasifikasi }\end{array}$ & 17 & 100 \\
\hline & & & Secara keseluruhan & 152 & 85,5 \\
\hline \multirow[t]{4}{*}{2.} & Bosshard $\mathrm{PP}^{15}$ & VDRL & Primer & 59 & 61,0 \\
\hline & & & Sekunder & 66 & 97,0 \\
\hline & & & Laten & 25 & 96,0 \\
\hline & & & Secara keseluruhan & 156 & 83,3 \\
\hline
\end{tabular}

RPR: Rapid Plasma Reagin, VDRL: Venereal Disease Research Laboratory

Tabel 3. Efektivitas RPR otomatis dan RPR kartu

\begin{tabular}{|c|c|c|c|c|c|}
\hline \multirow[t]{2}{*}{ No. } & \multirow[t]{2}{*}{ Peneliti utama } & \multirow[t]{2}{*}{ Hasil } & \multicolumn{3}{|c|}{ Pemeriksaan serologis } \\
\hline & & & $\begin{array}{c}\text { RPR } \\
\text { otomatis }\end{array}$ & $\begin{array}{l}\text { RPR } \\
\text { kartu }\end{array}$ & RPR otomatis dan RPR kartu \\
\hline \multirow[t]{4}{*}{1.} & Lee $\mathrm{JH}^{18}$ & Sensitivitas (\%) & 52,5 & 86,4 & - \\
\hline & & Spesifisitas (\%) & 94,3 & 94,3 & - \\
\hline & & $P_{o}(\%)$ & - & - & 78,6 \\
\hline & & $\kappa$ & - & - & 0,565 \\
\hline \multirow[t]{7}{*}{2.} & Sanfilippo $\mathrm{AM}^{19}$ & Sensitivitas (\%) & 100 & 76,0 & - \\
\hline & & Spesifisitas (\%) & 99,4 & 99,8 & - \\
\hline & & $\operatorname{NRP}(\%)$ & 80,7 & 90,5 & - \\
\hline & & NRN (\%) & 100 & 99,4 & - \\
\hline & & PPA $(\%)$ & - & - & $95,2-96,0$ \\
\hline & & NPA $(\%)$ & - & - & $96,0-98,8$ \\
\hline & & $\kappa$ & - & - & $0,763-0,920$ \\
\hline
\end{tabular}




\begin{tabular}{lllll} 
3. Tsuboi $\mathrm{M}^{27}$ & Sensitivitas (\%) & 98,7 & - & - \\
& Spesifisitas (\%) & 96,7 & - & - \\
NRP (\%) & 92,5 & - & - \\
& NRN (\%) & 99,4 & - & - \\
K & - & - & 0,94 \\
\hline
\end{tabular}

RPR: Rapid Plasma Reagin, RPR otomatis: pemeriksaan RPR menggunakan alat secara otomatis, RPR kartu: pemeriksaan RPR menggunakan kartu secara manual, $P_{o}$ : observed percentage of agreement, $\kappa:$ nilai kappa, NRP: Nilai Ramal Positif, NRN: Nilai Ramal Negatif, PPA: Positive Percent Agreement, NPA: Negative Percent Agreement

Tabel 4. Efektivitas pemeriksaan serologis spesifik treponema masing-masing literatur

\begin{tabular}{|c|c|c|c|c|c|}
\hline \multirow[t]{2}{*}{ No. } & \multirow[t]{2}{*}{ Peneliti utama } & \multirow{2}{*}{$\begin{array}{l}\text { Pemeriksaan } \\
\text { serologis }\end{array}$} & \multicolumn{3}{|c|}{ Hasil } \\
\hline & & & $\begin{array}{l}\text { Sensitivitas } \\
(\%)\end{array}$ & $\begin{array}{c}\text { Spesifisitas } \\
(\%)\end{array}$ & Lainnya \\
\hline 1. & Fakile $\mathrm{YF}^{28}$ & TP Rapid & $50,0-76,9$ & $99,0-99,4$ & $\begin{array}{l}\text { NRP 50,0\%-68,4\% } \\
\text { NRN } 98,6 \%-99,7 \%\end{array}$ \\
\hline 2. & Mehra B ${ }^{24}$ & TP Rapid & 92,86 & 98,28 & $\begin{array}{l}\text { NRP } 97,5 \% \\
\text { NRN } 95,0 \% \\
\text { к } 0,917\end{array}$ \\
\hline 3. & Bazzo ML ${ }^{29}$ & TP Rapid & $94,5-100$ & $91,5-100$ & $\begin{array}{l}\text { Akurasi 95,8\%-98,5\% } \\
\text { к 0,85-1 }\end{array}$ \\
\hline 4. & Bocoum FY ${ }^{30}$ & TP Rapid & $78,0-93,0$ & $95,0-98,0$ & - \\
\hline 5. & Pereira LE ${ }^{31}$ & TP Rapid & $66,7-95,7$ & $88,0-93,2$ & - \\
\hline 6. & Masenga $\mathrm{SK}^{32}$ & TP Rapid & 91,3 & 85,3 & - \\
\hline 7. & Lee $\mathrm{JH}^{33}$ & TP Rapid & 99,2 & 100 & - \\
\hline 8. & Fakile $\mathrm{YF}^{34}$ & TP Rapid & $50,0-100$ & $95,7-95,9$ & - \\
\hline 9. & Montaño $\mathrm{K}^{12}$ & TP Rapid & $82,5-100$ & $94,2-96,6$ & $\begin{array}{l}\text { NRP } 71,8 \% \\
\text { NRN } 100 \%\end{array}$ \\
\hline 10. & Smit PW 35 & TPHA & 50,5 & 99,7 & - \\
\hline 11. & Levchik $\mathrm{N}^{36}$ & TPHA & - & - & $\begin{array}{l}\text { Titik potong titer } 1: 20480 \\
\text { membedakan pasien normal dan } \\
\text { abnormal pada berbagai } \\
\text { parameter CSS }(\mathrm{p}<0,0001)\end{array}$ \\
\hline
\end{tabular}

TP Rapid: Treponema Pallidum Rapid, TPHA: Treponema Pallidum Haemagglutination Assay, NRP: Nilai Ramal Positif, NRN: Nilai Ramal Negatif, $\kappa:$ nilai kappa, CSS: Cairan Serebrospinal

\section{BAHASAN}

Sebuah skrining yang baik akan memberikan hasil positif jika seseorang mempunyai penyakit dan hasil negatif jika seseorang tidak mempunyai penyakit. ${ }^{37}$ Sementara itu, pemeriksaan diagnostik adalah pemeriksaan yang digunakan untuk menentukan diagnosis suatu penyakit. Pemeriksaan diagnostik terbaik disebut sebagai baku emas. ${ }^{38}$ Sebelumnya, baku emas untuk diagnosis definitif sifilis yang digunakan ialah Dark Field Examination (DFE). ${ }^{39,40}$ Namun, DFE bersifat subjektif sehingga digantikan dengan Polymerase Chain Reaction (PCR). ${ }^{39}$ Dalam pemeriksaan serologis sifilis, literatur-literatur yang didapatkan memiliki perbedaan standar untuk membandingan berbagai pemeriksaan sero- logis sifilis. Oleh karena itu, banyak nilai sensitivitas dan spesifisitas yang bervariasi dari berbagai literatur (Tabel 6, 7, 8, dan 9).

Efektivitas suatu pemeriksaan biasanya diukur berdasarkan validitasnya, baik sensitivitas maupun spesifisitasnya. ${ }^{38,41}$ Literatur yang dikaji dalam penelitian ini berfokus pada efektivitas pemeriksaan serologis non spesifik treponema dan pemeriksaan serologis spesifik treponema. Hasil penting lainnya juga terkait efektivitas pemeriksaan serologis sifilis tetap diperhatikan.

Dalam 10 tahun terakhir ini, terdapat lebih banyak literatur yang membahas RPR dibandingkan dengan VDRL, yaitu sebanyak 12 literatur. VDRL lebih baik daripada RPR dalam hal sensitivitas, Nilai Ramal Positif (NRP), dan Nilai Ramal Negatif 
(NRN). Namun, pada spesifisitas terlihat RPR lebih unggul daripada VDRL. VDRL memiliki sensitivitas $44,4 \%-100 \%$, spesifisitas 74,0\%-100\%, NRP 84,0\%-100\%, dan NRN 79,2\%-100\%. ${ }^{15,17,21,24}$ RPR menunjukkan sensitivitas $9,1 \%-100 \%$, spesifisitas 80,8\%-100\%, NRP 76,2\%-100\%, dan NRN 65,5\%-100\%.13,16,18-22,26,27 Selain itu, RPR dibandingkan TPHA memiliki observed percentage of agreement $\left(P_{o}\right) 88,0 \% .^{20}$

Berdasarkan stadium sifilisnya, sensitivitas RPR pada stadium sifilis primer jauh lebih baik daripada VDRL, akan tetapi pada stadium sifilis sekunder hasil sensitivitas lebih baik terlihat pada VDRL. Pada stadium laten karena terdapat perbedaan klasifikasi pada literatur sehingga tidak dapat ditentukan pemeriksaan serologis non spesifik treponema yang lebih baik antara RPR dan VDRL. Walaupun demikian, sensitivitas RPR secara keseluruhan dibandingkan dengan VDRL sedikit lebih tinggi dari kedua literatur yang dikaji (Tabel 7). ${ }^{13,15}$

Pada perbandingan antara RPR otomatis dan RPR kartu didapatkan RPR kartu hanya unggul dalam hal spesifisitas daripada RPR otomatis yang lebih baik dalam hal sensitivitas, NRP, dan NRN. RPR otomatis memiliki sensitivitas 52,5\%-100\%, spesifisitas 94,3\%-99,4\%, NRP 80,7\%-92,5\%, dan NRN 99,4\%-100\%..$^{18,19,27}$ Sementara itu, RPR kartu memiliki sensitivitas 76\%86,4\%, spesifisitas 94,3\%-99,8\%, NRP $90,5 \%$, dan NRN 99,4\%..$^{18,19}$

Sensitivitas yang tinggi menandakan rendahnya hasil negatif palsu, sedangkan jika sensitivitasnya rendah artinya terdapat banyak hasil negatif palsu. ${ }^{38,41}$ Pada penelitian untuk menentukan ada tidaknya sifilis kongenital pada bayi baru lahir, sensitivitas RPR yang rendah terlihat sebesar 9,1\%. ${ }^{21}$ Kecurigaan adanya sifilis kongenital tinggi jika pada bayi ditemukan titer RPR meningkat minimal empat kali lebih tinggi daripada serum ibu. Meskipun demikian, kecurigaan sifilis kongenital tidak dapat langsung disingkirkan hanya dengan tidak terpenuhinya kriteria peningkatan RPR empat kali lipat pada bayi dibandingkan dengan pada serum ibu. ${ }^{39,40}$ Perlu pemeriksaan lebih lanjut untuk menentukan ada tidaknya sifilis kongenital, seperti hitung darah lengkap, hitung jenis leukosit, hitung trombosit, radiografi tulang panjang, serta analisis cairan serebrospinal (CSS) dengan VDRL, hitung sel, dan protein. ${ }^{40}$

Pada kasus neurosifilis, RPR menunjukkan hasil negatif palsu. ${ }^{23}$ Analisis CSS lebih diutamakan menggunakan VDRL daripada RPR,${ }^{39}$ akan tetapi, literatur yang membandingkan pemeriksaan serologis non spesifik treponema menggunakan CSS memperlihatkan Intraclass Correlation Coefficient (ICC) sebesar 0,99 untuk VDRL terhadap RPR. Hal ini menunjukkan RPR dapat menjadi pemeriksaan alternatif untuk mendiagnosis neurosifilis. ${ }^{16}$ CSS yang diperiksa dengan VDRL memiliki spesifisitas tinggi sehingga dianggap sebagai diagnostik dari neurosifilis. Walaupun demikian, kejadian VDRL negatif dari CSS dapat terjadi pada 50\% sampel neurosifilis karena kurangnya sensitivitas. $^{40,42}$ Jika hal ini terjadi, analisis CSS dapat dilakukan dengan Fluorescent Treponemal Antibody Absorption (FTAABS) yang memiliki sensitivitas tinggi. Pada prinsipnya, tidak ada satu tes tunggal yang dapat menegakkan diagnosis neurosifilis. ${ }^{40}$

Di samping itu, RPR juga menunjukkan hasil negatif palsu pada kasus sifilis okuler dengan HIV positif. ${ }^{25}$ Pasien HIV positif dapat memberikan hasil negatif palsu dan positif palsu pada pemeriksaan serologis sifilis. ${ }^{39,40,43}$ Tidak adanya tanda spesifik untuk sifilis dan hasil pemeriksaan negatif dapat menyebabkan keterlambatan diagnosis pada sifilis okuler. ${ }^{43}$ Jika hasil pemeriksaan serologis negatif bahkan setelah pemeriksaannya diulangi, pemeriksaan diagnostik lainnya disarankan untuk dilakukan. ${ }^{39}$ Pada kasus ini, setelah dilakukan pemeriksaan ulang hasilnya reaktif dengan pemeriksaan serologis spesifik treponema terlebih dulu dan dilanjutkan RPR. ${ }^{25}$

Kesalahan mengidentifikasi penyakit atau positif palsu dapat memengaruhi spesifisitas pemeriksaan. ${ }^{41}$ Hasil positif palsu sebesar 8,2\% dari RPR terlihat pada pasien malaria Plasmodium vivax. ${ }^{14}$ Titer RPR $\leq 1: 4$ tampak pada sebagian besar hasil positif palsu pemeriksaan serologis non spesifik treponema, ${ }^{39}$ namun, pada literatur 
ini didapatkan setengah dari hasil positif palsunya memiliki titer $\mathrm{RPR} \geq 1: 8 .{ }^{14}$ Oleh karena itu, pemeriksaan ulang disarankan untuk dilakukan dan dilanjutkan dengan pemeriksaan serologis spesifik treponema. ${ }^{39}$

Pada TPHA didapatkan sensitivitas $50,5 \%$ dan spesifisitas $99,7 \% .{ }^{35}$ Spesifisitas yang tinggi pada TPHA membantu penegakan diagnosis neurosifilis. Distribusi titer TPHA berbeda secara bermakna antara pasien dengan nilai CSS normal dan abnormal. Titer TPHA <1:20480 sering ditemukan pada pasien nilai CSS normal dan $\geq 1: 20480$ pada pasien nilai CSS abnormal dengan kelainan CSS lebih parah. ${ }^{36}$

Sama seperti halnya TPHA, TP Rapid juga memperlihatkan spesifisitas yang tinggi. Walaupun demikian, baik dalam hal sensitivitas maupun spesifisitas TP Rapid masih lebih baik dibandingkan dengan TPHA. TP Rapid mempunyai sensitivitas $50,0 \%-100 \%$ dan spesifisitas $85,3 \%$ $100 \% .^{12,24,28-34}$

Penilaian lain yang perlu diperhatikan ialah nilai kappa $(\kappa)$ yang dapat bervariasi dari angka -1 sampai 1 , dimana -1 artinya ketidaksepakatan sempurna dan 1 artinya kesepakatan sempurna. ${ }^{44}$ RPR otomatis dan RPR kartu memiliki $\kappa$ 0,565-0,940 yang artinya terdapat kesepakatan sedang sampai hampir sempurna. ${ }^{18,19,27,44}$ Sementara itu, $\kappa$ dari TP Rapid dan TPHA sebesar 0,917 menunjukkan kesepakatan hampir sempurna. ${ }^{24,44}$ Pada literatur yang meneliti berbagai jenis TP Rapid dibandingkan dengan Chemiluminescent Microplate Immunoassay (CMIA), TPHA, dan FTA-ABS mempunyai $\kappa 0,85-1$ yang artinya terdapat kesepakatan hampir sempurna. ${ }^{29,44}$

Sensitivitas dari RPR, VDRL, dan TP Rapid termasuk dalam kategori tinggi. ${ }^{12,13 \text {, }}$ 15-22,24,26-34 Spesifisitas tinggi didapatkan pada TPHA dan TP Rapid. ${ }^{12,24,28-35}$ RPR dan VDRL digunakan sebagai skrining karena sensitivitasnya yang tinggi ${ }^{8,42}$ Di pihak lain, TPHA dan TP Rapid digunakan sebagai pemeriksaan untuk mengonfirmasi kecurigaan adanya sifilis. ${ }^{8}$ Pemeriksaan ini memerlukan spesifisitas yang tinggi. ${ }^{42}$ Selain itu, biaya merupakan hal lain yang perlu dipertimbangkan terkait skrining dan diag- nosis. ${ }^{8,37,42}$ Biaya yang jauh lebih murah dimiliki oleh RPR dan VDRL jika dibandingkan dengan TPHA dan TP Rapid. ${ }^{45}$

\section{SIMPULAN}

Skrining sifilis efektif dilakukan dengan RPR dan VDRL, sedangkan diagnostik sifilis efektif dilakukan dengan TP Rapid dan TPHA. Pada pemeriksaan serologis non spesifik treponema efektif, khususnya untuk skrining VDRL lebih unggul daripada RPR sedangkan pada pemeriksaan serologis spesifik treponema efektif khususnya untuk diagnosis, TP Rapid lebih unggul daripada TPHA. Perlu diperhatikan bahwa pemeriksaan serologis non spesifik treponema dan pemeriksaan serologis spesifik treponema menunjang hasil satu sama lain.

\section{Konflik Kepentingan}

Penulis menyertakan tidak terdapat konflik kepentingan dalam studi ini.

\section{DAFTAR PUSTAKA}

1. Rowley J, Hoorn S Vander, Korenromp E, Low $\mathrm{N}$, Unemo M, Abu-Raddad LJ, et al. Chlamydia, gonorrhoea, trichomoniasis and syphilis: Global prevalence and incidence estimates, 2016. Bull World Health Organ. 2019;97(8):548-62.

2. World Health Organization (WHO). Data on Syphilis [Internet]. World Health Organization. 2019 [cited 2020 Sep 16]. Available from: https://www.who.int/data/gho/data/themes/topics/topicdetails/GHO/data-on-syphilis

3. World Health Organization (WHO). WHO publishes new estimates on congenital syphilis [Internet]. World Health Organization. 2019 [cited 2020 Sep 16]. Available from: https://www.who.int/reproductivehealth/congenital-syphilisestimates/en/

4. World Health Organization (WHO). Baseline report on global sexually transmitted infection surveillance. 2012.

5. World Health Organization (WHO). Global health sector strategy on sexually transmitted infections 2016-2021 towards ending STIs. World Health Organization. 2016.

6. Lin JS, Eder ML, Bean SI. Screening for 
syphilis infection in pregnant women updated evidence report and systematic review for the US preventive services task force. JAMA - J Am Med Assoc. 2018;320(9):918-25.

7. An Q, Wejnert C, Bernstein K, Paz-Bailey G. Syphilis screening and diagnosis among men who have sex with men, 20082014, 20 U.S. Cities. J Acquir Immune Defic Syndr. 2017;75:S363-9.

8. Kementerian Kesehatan Republik Indonesia. Pedoman Tata Laksana Sifilis Untuk Pengendalian Sifilis di Layanan Kesehatan Dasar. Jakarta: Direktorat Jenderal Pengendalian Penyakit dan Penyehatan Lingkungan, 2013;p. 1.

9. Tuddenham SA, Zenilman JM. Syphilis. In: Kang S, Amagai M, Bruckner AL, Enk AH, Margolis DJ, McMichael AJ, et al, editors. Fitzpatrick's Dermatology (9th ed). New York: McGraw Hill Education, 2019; p. 3145-72.

10. Winchester CL, Salji M. Writing a literature review. J Clin Urol. 2016;9(5):308-12.

11. Maggio LA, Sewell JL, Artino AR. The literature review: a foundation for highquality medical education research. J Grad Med Educ. 2016;8(3):297-303.

12. Montaño K, Flores A, Villarroel-Torrico M, Cossio N, Salcedo-Meneses A, ValenciaRivero C, et al. Rapid diagnostic testing to improve access to screening for syphilis in prison. Rev Esp Sanid Penit. 2018;20(3):81-6.

13. Shukla M, Sun Y, McCormick J, Hopkins A, Pereira L, Gaynor A, et al. Development of a syphilis serum bank to support research, development, and evaluation of syphilis diagnostic tests in the United States. Diagn Microbiol Infect Dis. 2020;96(1):114913.

14. Maves RC, Dean K, Gadea N, Halsey ES, Graf PCF, Lescano AG. False-positive rapid plasma reagin testing in patients with acute Plasmodium vivax malaria: A case control study. Travel Med Infect Dis. 2014;12(3):268-73.

15. Bosshard PP. Usefulness of IgM-specific enzyme immunoassays for serodiagnosis of syphilis: comparative evaluation of three different assays. J Infect. 2013;67(1):35-42.

16. Versiani I, Cabral-Castro MJ, Puccioni-Sohler M. A comparison of nontreponemal tests in cerebrospinal fluid for neuro- syphilis diagnosis: Equivalent detection of specific antibodies. Arq Neuropsiquiatr. 2019;77(2):91-5.

17. Marra CM, Maxwell CL, Dunaway SB, Sahi SK, Tantalo LC. Cerebrospinal fluid Treponema pallidum particle agglutination assay for neurosyphilis diagnosis. $\mathrm{J}$ Clin Microbiol. 2017;55(6):1865-70.

18. Lee J-H, Lim CS, Lee M-G, Kim H-S. Comparison of an automated rapid plasma reagin (RPR) test with the conventional RPR card test in syphilis testing. BMJ Open. 2014;4(12):-e005664.

19. Sanfilippo AM, Freeman K, Schmitz JL. Comparison of manual and fully automated AIX1000 rapid plasma reagin assays for laboratory diagnosis of syphilis. J Clin Microbiol. 2018;56(8):1-8.

20. Negash M, Wondmagegn T, Geremew D. Comparison of RPR and ELISA with TPHA for the diagnosis of syphilis: implication for updating Syphilis Pointof-Care Tests in Ethiopia. J Immunol Res. 2018;2018:2978419.

21. Marangoni A, Foschi C, Capretti MG, Nardini P, Compri M, Corvaglia LT, et al. Contribution of a comparative western blot method to early postnatal diagnosis of congenital syphilis. Clin Vaccine Immunol. 2016;23(5):410-6.

22. Shukla MR, Deutsch JW, Pereira LE, Kersh EN, Fakile YF. Development of a novel magnetic particle-based agglutination immunoassay for anticardiolipin antibody detection in syphilis. Sex Transm Infect. 2020;96(6):411-6.

23. Prynn J, Hussain A, Winnett A. Diagnosing neurosyphilis: a case of confusion. BMJ Case Rep. 2016 Oct;2016.

24. Mehra B, Bhattar S, Saxena S, Rawat D, Bhalla P. Evaluation of SD BIOLINE syphilis 3.0 for rapid diagnosis of syphilis: report from a regional sexually transmitted infection reference laboratory in North India. J Lab Physicians. 2016;8(1):36-40.

25. Motlagh MN, Javid CG. Presentation of ocular syphilis in a HIV-Positive patient with false-negative serologic screening. Case Rep Infect Dis. 2019;2019(Cmv):1-5.

26. Liu C, Ou Q, Chen H, Chen J, Lin S, Jiang L, et al. The diagnostic value and performance evaluation of five serological tests for the detection of Treponema pallidum. J Clin Lab Anal. 2014;28(3):-204-9. 
27. Tsuboi M, Nishijima T, Aoki T, Teruya K, Kikuchi Y, Gatanaga H, et al. Usefulness of automated latex turbidimetric rapid plasma reagin test for diagnosis and evaluation of treatment response in syphilis in comparison with manual card test: A prospective cohort study. J Clin Microbiol. 2018;56(11):1-8.

28. Fakile YF, Markowitz N, Zhu W, Mumby K, Dankerlui D, McCormick JK, et al. Evaluation of a Rapid Syphilis Test in an Emergency Department Setting in Detroit, Michigan. Sex Transm Dis. 2019;46(7):429-33.

29. Bazzo ML, da Motta LR, Rudolf-Oliveira RCM, Bigolin A, Golfetto L, Mesquita F, et al. Evaluation of seven rapid tests for syphilis available in Brazil using defibrinated plasma panels. Sex Transm Infect. 2017;93(S4):S46-50.

30. Bocoum FY, Ouédraogo H, Tarnagda G, Kiba A, Tiendrebeogo S, Bationo F, et al. Evaluation of the diagnostic performance and operational characteristics of four rapid immunochromatographic syphilis tests in Burkina Faso. Afr Health Sci. 2015;15(2):360-7.

31.31. Pereira LE, McCormick J, Dorji T, Kang J, Sun Y, Shukla M, et al. Laboratory evaluation of a commercially available rapid syphilis test. J Clin Microbiol. 2018 Oct;56(10).

32. Masenga SK, Mweemba M, Kachele A, Chalubemba Y, Toloka P, Hamooya BM. Lessons from a comparison of immuno-chromatographic and chemiluminescent micro-particle immunoassay in the diagnosis of syphilis. BMC Res Notes. 2018;11(1):701.

33. Lee J-H, Lim CS, Lee M-G, Kim H-S. Evaluation of a rapid immuno-chromatographic treponemal antibody test comparing the treponema pallidum particle agglutination assay. J Clin Lab Anal. 2015;29(5):383-6.

34. Fakile YF, Brinson M, Mobley V, Park IU, Gaynor AM. Performance of the syphilis health check in clinic and laboratory-based settings. Sex Transm
Dis. 2019;46(4):250-3.

35. Smit PW, van der Vlis T, Mabey D, Changalucha J, Mngara J, Clark BD, et al. The development and validation of dried blood spots for external quality assurance of syphilis serology. BMC Infect Dis. 2013;13:102.

36. Levchik N, Ponomareva M, Surganova V, Zilberberg N. Treponema Pallidum haemagglutination assay serum titres as a predictor of cerebrospinal fluid abnormalities in patients with syphilis. Acta Derm Venereol. 2015;95(7):841-2.

37. Maxim LD, Niebo R, Utell MJ. Screening tests: A review with examples. Inhal Toxicol. 2014;26(13):811-28.

38. Parikh R, Mathai A, Parikh S, Chandra Sekhar $\mathrm{G}$, Thomas R. Understanding and using sensitivity, specificity and predictive values. Indian J Ophthalmol [Internet]. 2008;56(1):45-50.

39. Janier M, Unemo M, Dupin N, Tiplica GS, Potočnik M, Patel R. 2020 European guideline on the management of syphilis. J Eur Acad Dermatology Venereol. 2020;1-15. Doi: 10.1111/jdv.16946

40. Workowski KA, Bolan GA. Centers for Disease Control and Prevention. Sexually transmitted diseases treatment guidelines, 2015. Vol. 64, Morbidity and Mortality Weekly Report. 2015.

41. Lalkhen AG, McCluskey A. Clinical tests: Sensitivity and specificity. Contin Educ Anaesthesia, Crit Care Pain. 2008;8(6): 221-3.

42. Nayak S, Acharjya B. VDRL test and its interpretation. Indian J Dermatol. 2012; 57(1):3-8.

43. Lynn WA, Lightman S. Syphilis and HIV: a dangerous combination. Rev Lit Arts Am. 2004;4(July):456-66.

44. Hallgren KA. Computing inter-rater reliability for observational data: an overview and tutorial. Tutor Quant Methods Psychol. 2012;8(1):23-34.

45. Peeling RW, Ye H. Diagnostic tools for preventing and managing maternal and congenital syphilis: an overview. Bull World Health Organ. 2004;82(6):439-46. 